\title{
Humanities
}

\section{Chief Complaint}

\author{
Melissa-Rosina Pasqua, BSc ${ }^{1}$ \\ ${ }^{1}$ Faculty of Medicine, University of Ottawa
}

A B STRACT

In the small group sessions of undergraduate medical education at the University of Ottawa, students are presented with a patient's chief complaint in a module that is clear-cut and objective. The cases are often idealistic in a way that can be sometimes statistically rare, but once in a while the patient passes away, leaving students slightly disappointed but undisturbed. Exposure to a patient's triumphs and tribulations may be only a few minutes long, but for the patient and their family, cancer represents a man who is in constant fear of a group of cells killing him, or a father who will never see his grandchildren, or a wife whose absence leaves a sting to everyday life. This poem is an attempt to give a voice to the patient outside the constraints of a presented case, whether it is case-based learning or a presentation in a hospital conference room, and instead to give life to a scenario that is greyer than the black and white typed notes make it out to be.

RÉSUMÉ

Dans les séances en petits groupes, faisant partie de la formation médicale de premier cycle à l'Université d'Ottawa, les étudiants font face à la plainte principale d'un patient dans un module qui est clair et objectif. Les cas sont souvent idéalistes, dans un contexte qui peut parfois être statistiquement rare. De temps en temps, par contre, le patient décède, laissant les étudiants quelque peu déçus. L'exposition aux triomphes et tribulations d'un patient peut ne durer que quelques minutes, mais pour le patient et sa famille, le cancer représente un homme qui vit dans la peur constante qu'un groupe de cellules le tuera, ou un père qui ne verra jamais ses petits-enfants, ou une épouse dont l'absence laisse une douleur à la vie quotidienne. Ce poème tente de donner une voix au patient en dehors des contraintes d'un cas présenté, que ce soit à travers l'apprentissage par cas ou une présentation dans une salle de conférence de I’hôpital, et au lieu, donner vie à un scénario qui est plus gris que font sembler les notes dactylographiées en noir et blanc.

The patient is a 55 year old male, presenting with a 6 month history of progressive shortness of breath, chest pain, dysphonia, and constitutional symptoms which included weight loss and night sweats -

"This last summer was a vague memory

of puzzle pieces that I attempted to assemble together,

because despite the crisp breeze and warm weather,

I felt under a cloud.

A voice gone hoarse and a persistent cough

laid a shroud of obscurity in my mind, but what kind of heavy cloak weighed me down, unable to run freely with my son playing football? Yet with the illusion of being out of shape, I saw my shape wither away in the mirror, bones appearing where flesh once was, a paradox I could not figure out."
His chief complaint at first visit was a two-day history of hemoptysis -

"Aunt from aunt, nephew from nephew, there were only a few of them who did not notice a change in the person whose exterior was stagnant for years. I pushed down the fears about my weight or my pallor, yet the family reunion turned sour when my chest roared with bronchial cries of mutiny, and out came a red badge of courage on my napkin. Not since Lady Macbeth had someone hated a damned spot so. I felt I would drown in that spot, as if the puddle would expand into an ocean, where a whirlpool of images from the cigarette warning labels that l'd so stubbornly ignored would pull me in to face my worst nightmares."

Keywords: poetry, medical education 


\section{Humanities}

Investigations showed low hemoglobin, low sodium likely due to the paraneoplastic Syndrome of Inappropriate Antidiuretic Hormone, and a left upper lobe nodule on chest X-ray -

"The physician glowed under the light

of the black and white image of my insides,

and pointed to the cloudy smudge that was killing me.

So there it was, that little puff of death,

the one that slowly managed to take my breath away,

to take my life away before I could say a word of defense.

In the meantime, I felt my sense of permanence in this world slip out of my fingers,

only for the dread and numbness to linger long enough to replace it."

- consistent with a diagnosis of a lung cancer, where biopsy specified this as squamous cell carcinoma. Risk factors included a 20pack year history -

"If I could have revisited my younger selves

to pluck every cigarette from their mouths,

I would have done so without shame,

but how am I to blame for being victim to

Man's unwavering lack of acceptance

that he is not but an erasable spot in this world?"

- which, along with the neoplasm, likely contributed to the low scores on pulmonary function tests. Fitness tests, along with CT, showed an inoperable, unresectable mass -

"The only thing that could save me had already passed me by, but yet the physician did try to offer me a sliver of hope when they -"

- offered a treatment of chemotherapy, which included Cisplatin and Vincristine, as well as radiation -

"Bags filled with alien-named poisons were brought to me by women who were cloaked in blue gowns,

only to protect themselves from the very liquids

that they were injecting into my veins.

The radiation was the same,

a game of burning laser tag on my chest.

The rest was pills to be taken at home."

The patient experienced the typical side effects, such as nausea and vomiting -

"I could see my wife from the corner of my eye, her face buried into my son's shoulder as she cried, while I clasped for dear life the white porcelain, only to emit projectile acid into the bowl.

I stared at the floating remnants of the dinner she had slaved over, my favourite dish to pick up my mood."
- but despite treatment, the patient's following PET scan revealed metastases to the liver -

"No matter the chemical torture I put myself through, the devil in my lung managed to spew into the other vital organs of my body. I suppose one home was not enough for the vile creature, who attempted to eat me from the inside out.

And yet again, my life slips from me more and more and more and more..."

Palliative support was given, and the patient signed a DNR document -

"The hospital room has a nice view.

What wasn't a nice view was the one below my chin,

the one of myself hooked up to a tank,

as if I was Jacques Cousteau exploring the sea.

How ironic that I still feel like I'm drowning.

I can see children playing outside in the sunshine,

likely similar to the grandchildren I will never see.

Children, do you not know your fortune?

Play, laugh, love, sing, run, BREATHE while you still can..."

The patient experienced abrupt hematemesis, chest pain, and shortness of breath. Upon CT, hospital-acquired pneumonia was diagnosed and IV antibiotics were given -

"All is a blur,

I cannot stir,

yet the whispers I do hear

from my loved ones are clear -

I am leaving this world loved."

Unfortunately, the pneumonia led to septic shock, which, despite intubation and steroid treatment, resulted in the demise of the patient.

Now onto the next case. 